The strategic implications of black empowerment in South Africa: a case study of boundary choice and client preferences in a small firm

WILLEM H. BOSHOFF

Stellenbosch Economic Working Papers: 07/10

KEYWORDS: BOUNDARIES, VERTICAL INTEGRATION, DEMAND-SIDE, BLACK EMPOWERMENT

JEL: L22, M14

WILLEM H. BOSHOFF

DEPARTMENT OF ECONOMICS

UNIVERSITY OF STELLENBOSCH

PRIVATE BAG X1, 7602

MATIELAND, SOUTH AFRICA

E-MAIL: WIMPIE2@SUN.AC.ZA 


\title{
The strategic implications of black empowerment in South Africa: a case study of boundary choice and client preferences in a small firm
}

\author{
WILLEM H. BOSHOFF
}

\begin{abstract}
This paper initiates a research programme on the strategic implications of BEE, through an in-depth case study of a small South African services firm. The case involves a meter-reading firm that has adapted flexible boundaries within the value chain to accommodate heterogeneous client preferences shaped by BEE policy. While the case is very specific, the analysis highlights three core features of BEE policy as a strategic variable. Firstly, the case supports an assertion that BEE policy is a demand-based intervention, altering client preferences regarding the value chain. Secondly, the case confirms that BEE is a market-based policy that may be implemented in a variety of ways by different clients. Thirdly, the case shows that firms do not passively respond to BEE policy but explore strategic responses that balance BEE requirements with other organizational goals.
\end{abstract}

Keywords: Boundaries, Vertical integration, Demand-side; Black empowerment

JEL codes: L22, M14 


\title{
The strategic implications of black empowerment in South Africa: a case study of boundary choice and client preferences in a small firm
}

\author{
Willem H. Boshoff ${ }^{1}$
}

Management research recognizes the role of government policy in shaping strategic business decisions (Hall and Soskice, 2001). The role of government policy is particularly significant in the South African context, as businesses have had to deal with extensive institutional change since 1994 (Chabane et al., 2006). A principal feature of this institutional change has been its focus on the redress of historic imbalances created under the Apartheid regime. In the business world, this focus has manifested in government's black economic empowerment (BEE) policy (Black, 2002). The literature has noted the role of BEE in mergers and acquisitions (Jackson et al., 2005), but research on the impact of BEE on strategic decisions and value chain structure is scarce. BEE research is of practical importance to managers, who seek to balance BEE requirements with a range of other competitive goals, and can also offer important insights to policymakers.

This paper initiates a research programme on the strategic implications of BEE, through an in-depth case study of a small South African services firm. The case involves a meterreading firm that has adapted its boundaries within the value chain to accommodate client preferences shaped by BEE policy. The case study consists of three steps. First, I show how BEE policy affects the preferences of meter-reading clients. Second, I show that the changes in client preferences generate changes in the boundaries of the firm, i.e. in the extent of its activities within the value chain. Third, I show that the firm does not merely respond to these preferences, but accommodates changes in preferences in a strategic manner that preserves its competitive advantage.

The case study is based on a setting where BEE policy is a dominant feature in the strategic landscape due to the large proportion of public sector clients in the meter-reading industry. Despite this idiosyncratic setting, the case provides a starting point for research on the

\footnotetext{
${ }^{1}$ Lecturer, Department of Economics, Stellenbosch University, Private Bag X1, Matieland, South Africa, 7602. E-mail: wimpie2@sun.ac.za Tel: +27 218082387.
} 
mechanisms through which BEE has changed value chain structures in South Africa. The case suggests that BEE affects the preferences of clients, which confirms the portrayal of BEE as demand-based (Jackson et al., 2005) and further shows that the implementation of BEE policy differs significantly among clients. The demand-altering effect and heterogeneous nature of BEE are important issues for the manager, who must understand the likely effects of BEE policy on his or her firm and formulate strategic responses that balance heterogeneous client preferences with firm competences and profit considerations. The case then explores flexible boundaries as one strategic response to this environment.

The paper falls into six main parts: the first part introduces the case, the second part considers data and methodological issues, and the remaining parts present the detailed case analysis and broader conclusions for BEE research in South Africa.

\section{CASE SETTING}

The firm under investigation is $\mathrm{MRS}^{2}$, a small South African firm providing meter-reading services to municipalities and private sector clients. Meter-reading refers to the periodic collection (reading) of water and electricity consumption data. The consumption data is registered on metering devices located at homes, industries and businesses and meterreaders visit each site in person to collect the consumption data. In developed countries meter-reading no longer involves visits in person and data is transmitted electronically, but this is not yet implemented extensively in South Africa (Clark, 2000). South African municipalities and private property managers therefore outsource meter-reading to private contractors.

The meter-reading process can be divided into three consecutive steps: (1) planning of monthly meter-reading projects according to dates set by clients; (2) collection of meterreadings; and (3) processing of meter-readings by uploading the data onto a central database, identifying discrepancies (and re-reading if required), and transmitting processed data to clients. Each of these steps involves a set of highly interdependent activities with a distinct knowledge base: planning requires the ability to manage human resources and

\footnotetext{
${ }^{2}$ Name changed for confidentiality reasons.
} 
adjust work schedules, collection requires geographic knowledge of the areas in which meter-readings are collected as well as numerical skills, and processing requires computer skills and a familiarity with meter-reading processing procedures. The meter-reading value chain can therefore be described as modular (Grant, 2006), as shown in Figure 1:

\section{INSERT FIGURE 1 ABOUT HERE}

This modular structure has enabled MRS to occupy a variety of positions along the value chain, that is, to choose a variety of boundaries along the value chain. To investigate this variety, the paper studies five clients with whom MRS has been involved from 1997 to 2007. These five clients represent $90 \%$ of MRS revenue over this period. Table 1 presents a summary of information for the five clients.

\section{INSERT TABLE 1 ABOUT HERE}

Information from invoices, supplemented by discussions with the owner, shed light on the vertical structure of MRS over this period. The data shows that MRS offered a verticallyintegrated service to client 1 . According to discussions with the owner, MRS offered such an integrated service since its foundation in 1989. However, for clients 2 to 5, all acquired after 1999, MRS has also rendered services limited to specific modules. Figure 2 summarizes the boundary configurations along the metering value chain suggested by the invoice data. Highlighted cells indicate activity by MRS, whereas blank cells indicate outsourced activity.

\section{INSERT FIGURE 2 ABOUT HERE}

Even though three types of boundary configurations are identified in Figure 2, these are not pre-defined. As will be shown in the empirical analysis, MRS created new configurations depending on the requirements of particular clients. Furthermore, it is important to note that the above-mentioned configurations do not follow one another in chronological order, but that several boundary configurations were operative simultaneously, as shown in Figure 3. 
Figure 3 shows that meter-reading projects have life times varying from one to ten years and illustrates the overlap in project life times. This confirms that MRS employs flexible boundaries to meet heterogeneous requirements, rather than a periodic adjustment of its overall boundaries. The empirical analyses following later in the thesis provides additional support that the boundaries are set in accordance with the requirements of particular projects.

The preceding description shows that MRS has evolved from a vertically integrated service provider in the mid-nineties to a solution provider offering client-specific services constructed using flexible boundaries along the value chain. I argue later that changes in the preferences of meter-reading clients, driven by BEE policy, explain the shift to flexible boundaries. Before considering these arguments, I discuss the data and methodological approach.

\section{DATA AND METHODOLOGY}

The paper involves a case study, which is an appropriate research strategy when the focus is both exploratory (as it allows for multiple forms of evidence) and explanatory (as it is better suited to developing "why" and "how" explanations than quantitative analysis) (Yin, 2003). For the purposes of this paper the MRS case is particularly useful in demonstrating the effect of BEE on the demand side of the market, as MRS and the meter-reading industry do not experience significant supply-side related changes over the same period (Siggelkow, 2007).

I was actively involved with MRS as a part-time consultant since 1999, during which I gained the spatial and temporal understanding necessary to study structural change at MRS. The research was conducted over December 2007 to June 2009, as part of a larger research project. The analysis relies on multiple sources of evidence, including documentary evidence, interviews and direct observation. I had extensive semi-structured discussions with the owner and IT manager of MRS and with MRS's joint venture partners. I complement interview evidence with documentary evidence, including tender documents and financial documents, as described in Table 2: 
INSERT TABLE 2 ABOUT HERE

Direct observation served as a reliability test for interview and documentary evidence, but where direct observation did provide specific operational evidence, its interpretation was discussed with MRS.

The case description and methodological discussion above now lead us to the case analysis. As discussed, the case analysis develops three propositions. First, that BEE policy affects the value chain preferences of meter-reading clients. Second, that the changes in the demand preferences of meter-reading clients generate changes in the boundaries of MRS. Third, that MRS acted strategically when changing its boundaries in order to balance these client pressures with the need to maintain its broader competitive advantage in the value chain.

\section{BLACK EMPOWERMENT AND PREFERENCES OF CLIENTS}

Since 1994, the post-Apartheid government in South Africa has embarked upon an ambitious social transformation programme in an attempt to address inequalities generated under the Apartheid system. An important component of this transformation effort has been the roll-out of an extensive black economic empowerment (BEE) policy. This policy has three focus areas, all aimed at assisting black South Africans in entering and succeeding in the mainstream economy: firstly, direct empowerment (referring to the increase in ownership and management by black persons); secondly, human resource development (referring to affirmative action and skills development among black employees); and, thirdly, indirect empowerment (referring to black business development and preferential procurement) (Republic of South Africa, 2006). An important feature of BEE, therefore, is that black ownership and management is not considered sufficient (or even necessary) to earn high BEE scores: suppliers also earn BEE points based on their own procurement and skills development decisions. The aim is, therefore, to alter demand along value chains in a cascading fashion, ensuring that the policy consequences filter throughout the economy. 
BEE policy is an incentive-based policy based on a scorecard system. Under the scorecard system, firms that engage in meaningful BEE practices earn BEE scores that enhance their ability to win government contracts (Burger and Jafta, 2006). The private sector has adopted similar practices in evaluating contracts (Republic of South Africa, 2006). The scorecard system, however, evolved slowly over time and the lack of uniform guidelines resulted in heterogeneous practices across sectors (Burger and Jafta, 2006). Consequently, policymakers introduced a balanced scorecard to make explicit the weights assigned to different aspects of empowerment. Table 3 presents the balanced scorecard:

INSERT TABLE 3 ABOUT HERE.

Despite the guidelines provided by the balanced BEE scorecard, actual BEE requirements vary significantly. This variety is at least partly a path-dependent result of pre-scorecard sector-specific initiatives to accelerate transformation, which have had to be incorporated into formal scorecards. More important, however, is that the variety is a function of implementation: certain features of BEE, such as community development, may be considered more important in certain contexts, depending inter alia on local political conditions. This implies that the official weights may differ from the implemented weights.

South African municipalities, who represent the largest client base in the meter-reading industry, increasingly emphasised empowerment goals - favouring increased procurement involvement of socially-disadvantaged suppliers. Whereas municipal clients historically viewed meter-reading as best performed by a single vertically-integrated company, I will show below that clients now prefer multiple players along the meter-reading value chain.

MRS competes for work through tender bidding processes and I study tender bid invitation documents and related written communication to assess the value chain preferences of MRS clients. Tender bid documents articulate value chain preferences well, as municipalities specify their requirements and preferences in these documents. Table 4 presents the evidence for the five major clients of MRS. 
The five clients represent approximately $90 \%$ of revenue over the study period. Value chain preferences are measured in two ways: first, via the bid evidence mentioned above, and, second, via semi-structured interviews. I summarize the evidence from the two sources in the third column, which is titled "value chain preference". The column distinguishes between clients with no strong value chain preferences and those with particular preferences and, for the latter group, a short description of the specific value chain issues they consider important.

Table 4 shows that the five clients have heterogeneous value chain preferences. One client prefers meter-reading firms to use locally procured labour from the areas in which the firms are collecting meter-readings. Two other clients expect more intensive collaboration efforts between meter-reading firms and favoured local suppliers, with the aim of improving the business skills of local suppliers. The remaining two clients have no strong preferences and are willing to accept the structure proposed by the bidding firm. MRS must choose its boundaries in this heterogeneous demand environment and I show next that this heterogeneity prompted MRS to adopt flexible boundaries.

\section{DEMAND PREFERENCES OF CLIENTS AND FIRM BOUNDARIES}

The heterogeneity in value chain preferences described in Table 2 may be correlated with the heterogeneity in MRS boundary decisions described earlier. In Table 3, I study whether the preferences of clients feature in the boundary decisions of MRS. The table relies on two sources of evidence to assess how boundary decisions respond to clients: documentary evidence and discussions with management. The findings are summarized in the final column by, firstly, classifying boundary responses at MRS into "none" and "adjust boundaries" and, secondly, mentioning to which modules MRS chooses to restrict its boundaries.

\section{INSERT TABLE 5 ABOUT HERE}

Table 5 shows that boundary decisions at MRS are highly correlated with the value chain preferences of its clients: Client 2 values community procurement and MRS responds to 
this preference by outsourcing the collection module. The value chain preferences of Clients 3 and 4 extend beyond community procurement and include both procurement and promotion of local business and MRS responds by restricting its boundaries to the processing module and outsourcing the collection and planning module. Clients 1 and 5 do not exhibit strong value chain preferences and MRS chooses to perform all activities inhouse. Heterogeneity in value chain preferences is reflected in heterogeneity in firm boundaries. Figure 4 highlights the modules in which MRS is active for each client:

\section{INSERT FIGURE 4 AROUND HERE.}

To guarantee the internal validity of the claim that it was demand-side pressures that led MRS to adopt flexible boundaries, it is necessary to eliminate potential supply-side explanations. One competing explanation could be that technological change has caused MRS boundary change. Hand-held devices, used to electronically capture readings in the field, are slowly replacing traditional paper-based meter-reading in South Africa. However, while the hand-held technology does generate minor reallocation of tasks among modules, the technology does not alter the modular structure of the value chain or favour vertical disintegration $^{3}$. Apart from technology, the literature suggests a range of conventional supply-side explanations for flexible boundaries, including transaction cost economics and neoclassical economic theories (Parmigiani, 2007). However, dimensions of asset specificity or production uncertainty did not change fundamentally since the late nineties, precluding these as serious alternative explanations for the MRS boundary decision (Williamson, 1975, Whinston, 2003).

\section{STRATEGIC BENEFITS OF FLEXIBLE BOUNDARIES}

Flexible boundaries may not appear to be a long-run strategic solution for MRS, given that clients increasingly prefer the involvement of more firms along the meter-reading value chain. If the majority of clients prefer vertically specialized players, why not permanently change the boundaries of the firm to adopt a fully specialized position in the value chain?

\footnotetext{
${ }^{3}$ Hand-held technology results in a re-allocation of tasks between the collection and processing modules, by allowing the upload of data and an important part of the processing activity to take place during the collection, rather than the processing, phase.
} 
From this perspective it would appear that MRS implements flexible boundaries to serve those few remaining clients still preferring a single vertically-integrated firm. However, the strategic benefits of flexible boundaries extend well beyond an ability to meet heterogeneous client preferences. In particular, the case suggests that flexible boundaries confer so-called architectural knowledge, i.e. knowledge of how the modules along the value chain interrelate and co-function to produce the final product (see Jacobides (2006)).

To understand the salience of architectural knowledge in meter-reading, consider clients 2 , 3 and 4, for which MRS restricts its boundaries to the processing module only. This specialized focus enables MRS to meet the value chain preferences of these clients, as it outsources the collection and planning modules to community-based firms. The problem with outsourcing to community-based firms is that they do not hold operational knowledge beyond their own activities and hold little knowledge of how modules co-function to produce the final product - an accurate meter reading delivered to the client on time. In contrast, MRS holds architectural knowledge of all modules and their interrelationships because of the vertically-integrated service it provides to Clients 1 and 5. A vertically integrated solution requires MRS to have knowledge of all modules and their interrelationships. If MRS chooses to restrict its boundaries and not provide a vertically integrated solution to clients 1 and 5 , it would not be able to manage the value chain for clients 2, 3 and 4: MRS would gradually lose the capability to understand and manage the interrelationships across the value chain.

MRS uses its architectural knowledge to undertake a managerial role to ensure the accuracy and timeliness of meter-readings. Electronic and printed marketing documents, with ubiquitous references to "management", "administration" and "experience" as well as similar references (to "operations management", among others) in tender bid documents provide evidence on this management role. MRS "management" involves more than the coordination of daily activity in a given meter-reading value chain, important as that may be. It also entails the establishment of the underlying language and organizing concepts used across the meter-reading value chain. At MRS, this language is articulated in the firm's unique proprietary computer software system. The software system assists MRS in 
establishing a standard language by specifying a vocabulary of organizing concepts ("meter books", "walk sequences") as well as a system of standard codes to be used, for example, by meter-readers when recording problems encountered during meter-reading (e.g. code "11" refers to inaccessible meters, code "12" to defective meters, etc.). Figure 5 illustrates the managerial role of MRS in the different modules and their interfaces:

\section{INSERT FIGURE 5 ABOUT HERE}

When asked about their management role in the value chain, MRS management noted that "the client wants you to involve these guys but they also want readings delivered on time without a lot of problems". Adopting such a management role provides MRS with a competitive advantage relative to the specialized community-based firms, as acknowledged by MRS: "I think our IT [the MRS meter-reading software system] and our experience of getting the job done is what sets us apart. You know, meter-reading is not just about reading, it's about planning and sticking to dates. A lot of guys [other meter-reading firms] just don't know how to do this and that's why they fail". MRS therefore adopts flexible boundaries rather than a fully specialized vertical position in order to both deal with heterogeneity in the preferences of its clients and because flexible boundaries enable MRS to continue to manage the entire value chain. In sum, the adoption of flexible boundaries was not merely a response to survive, but also a strategy to ensure growth going forward.

\section{DISCUSSION AND CONCLUSIONS}

The paper seeks to initiate a research programme on the strategic implications and, more specifically, the value chain and boundary implications of BEE policy in South Africa. The MRS case study is therefore a first attempt at analyzing the mechanisms through which BEE policy on the one hand is linked to strategic outcomes on the other hand. While the case is very specific, the analysis highlights three core features of BEE policy as a strategic variable.

Firstly, the case supports an assertion that BEE policy is a demand-based intervention. Policy documents in government and organizations representing business understand BEE 
policy as aiming to alter demand along value chains in a cascading fashion, ensuring that the policy consequences filter throughout the economy (Republic of South Africa, 2006, De Wet, 2007). The paper confirms this interpretation, providing systematic evidence of changes in demand-side preferences shaped by BEE considerations. The demand-side interpretation of BEE policy is also consistent with a view of BEE as a form of corporate social responsibility (CSR), albeit involuntary: CSR is recognized as demand-side driven: for example, in the international food and textile value chains, firms have developed outsourcing practices and governance mechanisms to accommodate smaller players, mostly because of demand-side pressure from activists and socially-conscious buyers (Gereffi et al., 2005).

Secondly, the case confirms that BEE is a market-based policy that may be implemented in a variety of forms. BEE policy documents emphasize that the BEE balanced scorecard (discussed earlier) enables agents to tailor their BEE strategy to their individual environments. The paper supports this view and shows that heterogeneity in BEE approaches generates substantial heterogeneity in demand-side preferences, even for small firms with only a few large clients. Different industries may also exhibit different patterns: the MRS case is set in the meter-reading industry, where clients strongly emphasize BEE's value chain aspects than the affirmative action employment or ownership aspects. The case then suggests that where South African firms face heterogeneous client preferences (because of heterogeneous BEE requirements) they may adopt flexible structures to accommodate variety. The use of flexible structures to deal with BEE is consistent with the recent strategy literature, on the strategic use of flexibility under conditions of uncertainty (Kogut and Kulatilaka, 2006, van Wyk et al., 2004), and specifically with the strategic value chain literature (Nadkarni and Narayanan, 2007).

Thirdly, the case shows that firms do not passively respond to BEE policy but explore strategic responses that balance BEE requirements with other organizational goals. MRS did not merely "respond" to the demand-side pressures, but implemented a particular boundary choice that carried architectural benefits. In particular, MRS employed flexibility in its boundaries that enabled the firm to accommodate joint ventures and the involvement 
of other firms while maintaining architectural knowledge allowing MRS to manage the overall value chain processes (Santos and Eisenhardt, 2005, Jacobides and Billinger, 2006). This strategy is consistent with the literature's view of flexible boundaries as both a cooperative and a competitive device: architectural management ensures cooperation across the value chain to improve efficiency, while it is also a distinctive capability distinguishing the firm from competitors.

The paper relies on a single case study to develop the arguments and this naturally requires more extensive research into a variety of industries to study the generality of the findings suggested here. Four areas are particularly important in future research. Firstly, it is necessary to understand under which conditions ownership and employment issues, rather than value chain issues, dominate the BEE requirements of clients. Secondly, it is crucially important to study the conditions under which firms will respond to BEE requirements: do firms (both local and international) avoid industries with particular BEE emphases and what is the role of competitive pressure? Thirdly, how do smaller and larger firms differ in their responses to BEE policy? Fourthly, and perhaps most important, how can firms develop value chain structures that both enhance their own competitive advantage and ensure sustainable long-run BEE partners in their value chains?

\section{References}

BLACK, P. A. (2002) On the Case for 'Black Economic Empowerment' in South Africa. South African Journal of Economics, 70(8), 1148-1162.

BURGER, R. \& JAFTA, R. (2006) Returns to Race: Labour Market Discrimination in PostApartheid South Africa. Stellenbosch Economic Working Papers: 04/06. Department of Economics, University of Stellenbosch.

CHABANE, N., GOLDSTEIN, A. \& ROBERTS, S. (2006) The Changing Face and Strategies of Big Business in South Africa: More Than a Decade of Democracy. Industrial and Corporate Change, 15(3), 549-577.

CLARK, A. (2000) Demand-side management investment in South Africa: barriers and possible solutions for new power sector contexts. Energy for Sustainable Development, 4(4), 27-35.

DE WET, W. (2007) Ontwikkelingsmoontlikhede vir swart ekonomiese bemagtiging. Pretoria, Afrikaanse Handelsinstituut.

GEREFFI, G., HUMPHREY, J. \& STURGEON, T. (2005) The governance of global value chains. Review of International Political Economy, 12(1), 78-104.

GRANT, R. M. (2006) The knowledge-based view of the firm. IN FAULKNER, D. O. \& CAMPBELL, A. (Eds.) The Oxford Handbook of Strategy. Oxford, Oxford University Press. 
HALL, P. A. \& SOSKICE, D. W. (2001) Varieties of Capitalism: The Institutional Foundations of Comparative Advantage, New York, Oxford University Press.

JACKSON, W. E., ALESSANDRI, T. M. \& BLACK, S. S. (2005) The price of corporate social responsibility: the case of black economic empowerment transactions in South Africa. Federal Reserve Bank of Atlanta.

JACOBIDES, M. G. (2006) The architecture and design of organizational capabilities. Industrial and Corporate Change, 15(151-171.

JACOBIDES, M. G. \& BILLINGER, S. (2006) Designing the boundaries of the firm: From "make, buy, or ally" to the dynamic benefits of vertical architecture. Organization Science, 17(249261.

KOGUT, B. \& KULATILAKA, N. (2006) Strategy, Heuristics, and Real Options. IN FAULKNER, D. O. \& CAMPBELL, A. (Eds.) The Oxford Handbook of Strategy. Oxford, Oxford University Press.

NADKARNI, S. \& NARAYANAN, V. K. (2007) Strategic schemas, strategic flexibility, and firm performance: The moderating role of industry clockspeed. Strategic Management Journal, 28(243-270.

PARMIGIANI, A. (2007) Why do firms both make and buy? An investigation of concurrent sourcing. Strategic Management Journal, 28(285-311.

REPUBLIC OF SOUTH AFRICA (2006) South Africa's economic transformation: A strategy for broad-based black economic empowerment. Pretoria, South Africa.

SANTOS, F. M. \& EISENHARDT, K. M. (2005) Organizational boundaries and theories of organization. Organization Science, 16(491-508.

SIGGELKOW, N. (2007) Persuasion with case studies. Academy of Management Journal, 50(2024.

VAN WYK, J., DAHMER, W. \& CUSTY, M. C. (2004) Risk Management and the Business Environment in South Africa. Long Range Planning, 37(259-276.

WHINSTON, M. D. (2003) On the Transaction Cost Determinants of Vertical Integration. Journal of Law, Economics and Organization, 19(1), 1-23.

WILLIAMSON, O. E. (1975) Markets and Hierarchies: Analysis and Antitrust Implications, New York, Free Press.

YIN, R. K. (2003) Case study research: design and methods, London, Sage Publications. 
FIGURE 1: Modular Structure of MRS Value Chain

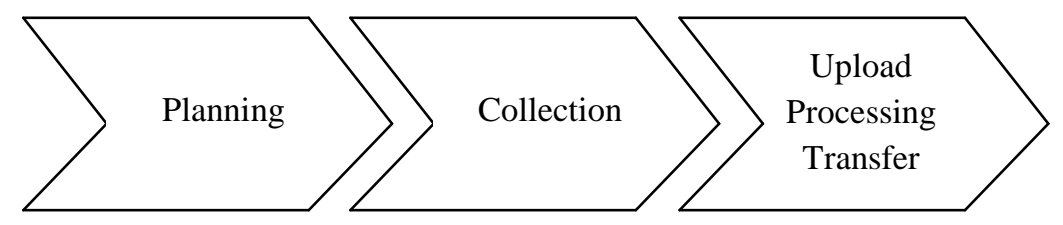

TABLE 1: Financial information showing modules in which MRS is active

\begin{tabular}{|c|c|c|c|}
\hline Project & Party invoiced & $\begin{array}{c}\text { Description of service on } \\
\text { invoice }\end{array}$ & $\begin{array}{c}\text { Modules in which MRS } \\
\text { involved }\end{array}$ \\
\hline Project 1 & MRS bills end customer & "Full meter-reading service" & $\begin{array}{c}\text { Planning, collection, } \\
\text { processing }\end{array}$ \\
\hline Project 2 & Subcontractor bills MRS & "Reading of water meters" & Planning, processing \\
\hline Project 3 & MRS bills joint venture & "Administration of meter- & Processing \\
& partner & reading services" & Processing \\
\hline Project 4 & MRS bills joint venture & "Administration of meter- \\
& partner & "Meading services" & processing \\
\hline Project 5 & MRS bills end customer & rendered, including \\
& & processing" & Planning, collection, \\
& & & proces \\
\hline
\end{tabular}


FIGURE 2:

Boundary configurations of MRS along metering value chain

\begin{tabular}{|c|l|l|l|}
\hline \multirow{2}{*}{ Boundary design } & \multicolumn{3}{|c|}{ Metering value chain } \\
\cline { 2 - 4 } & Planning & Collection & Processing \\
\hline Configuration 1 & & & \\
\hline Configuration 2 & & & \\
\hline Configuration 3 & & & \\
\hline
\end{tabular}

FIGURE 3:

Chronologies of projects with different boundary configurations

\begin{tabular}{|c|c|c|c|c|c|c|c|c|c|c|c|}
\hline \multirow{2}{*}{} & \multicolumn{7}{|c|}{ Project } & \multicolumn{7}{|c|}{} & \\
\cline { 2 - 12 } & 1997 & 1998 & 1999 & 2000 & 2001 & 2002 & 2003 & 2004 & 2005 & 2006 & 2007 \\
\hline Project 1 & & & & & & & & & & & \\
\hline Project 2 & & & & & & & & & & & \\
\hline Project 3 & & & & & & & & & & & \\
\hline Project 4 & & & & & & & & & & & \\
\hline Project 5 & & & & & & & & & & & \\
\hline
\end{tabular}


TABLE 2:

Sources of Evidence

\begin{tabular}{|c|c|c|c|}
\hline $\begin{array}{l}\text { Evidence } \\
\text { Source }\end{array}$ & Association between Boundaries and Demand & Rival Explanations & $\begin{array}{l}\text { Strategic Rationale and } \\
\text { Verifying Induced Theory }\end{array}$ \\
\hline \multirow[t]{2}{*}{ Interviews } & MRS management & MRS management & MRS management \\
\hline & Joint venture partners & & $\begin{array}{l}\text { Joint venture partners } \\
\text { IT officer }\end{array}$ \\
\hline Documentary & Tender invitation documents outlining & Tender reply documents & Attendance register for tender \\
\hline evidence & empowerment and service requirements and tender & & bid meetings \\
\hline (from tender & reply documents outlining the firm's proposal for & & \\
\hline bids) & the particular tender & & \\
\hline
\end{tabular}




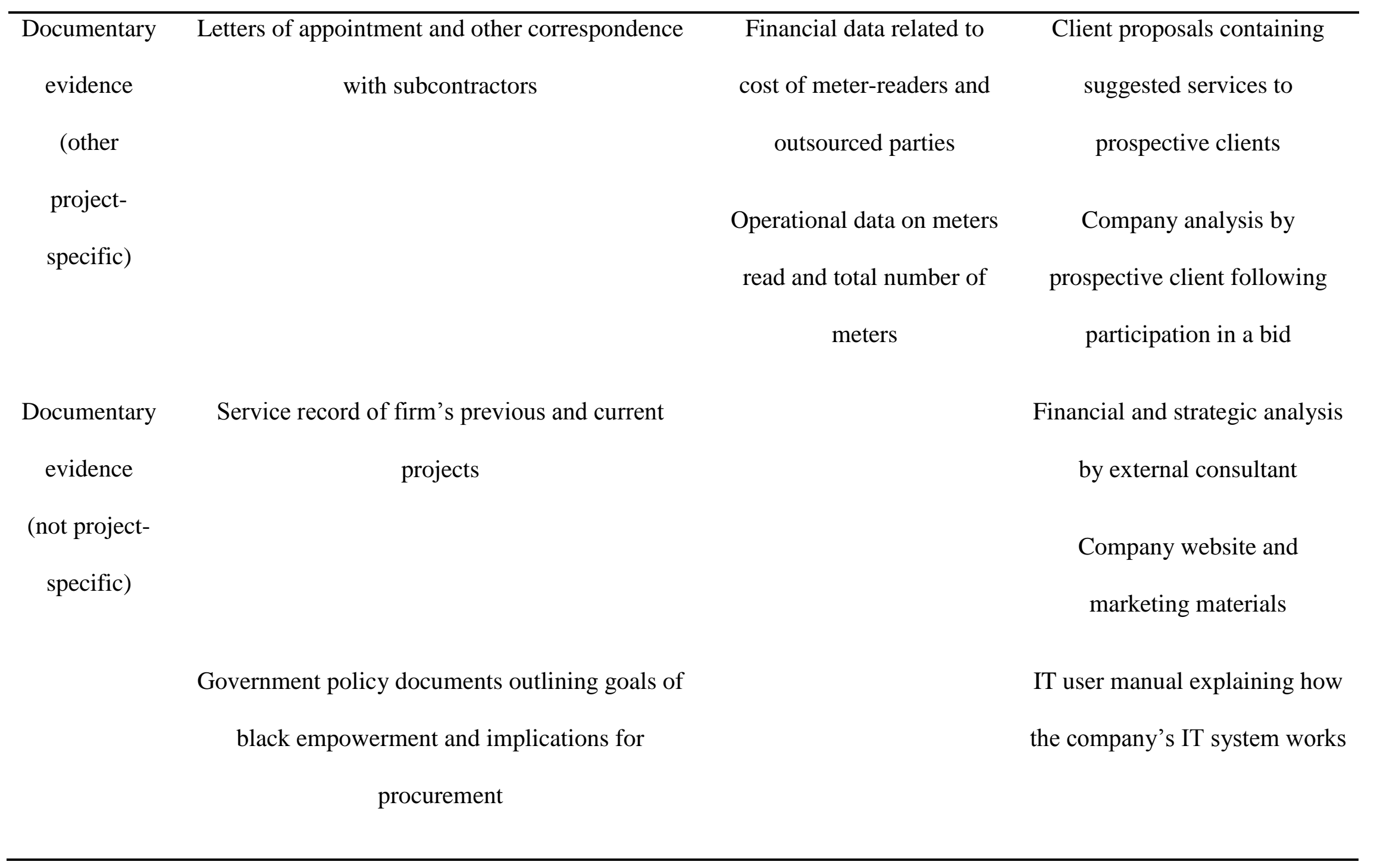


TABLE 3:

BEE scorecard

\begin{tabular}{|l|c|}
\hline Component & Weight \\
\hline Direct empowerment & $20 \%$ \\
\hline Equity ownership & $10 \%$ \\
\hline Management \\
\hline Human resource development \\
\hline Affirmative action \\
\hline Skills development & $10 \%$ \\
\hline Indirect empowerment & $20 \%$ \\
\hline Preferential procurement & $20 \%$ \\
\hline Enterprise development & $10 \%$ \\
\hline Residual \\
\hline Sector specific component & $10 \%$ \\
\hline
\end{tabular}

Source: Republic of South Africa (2006) 
TABLE 4: Views of MRS Clients on the Value Chain

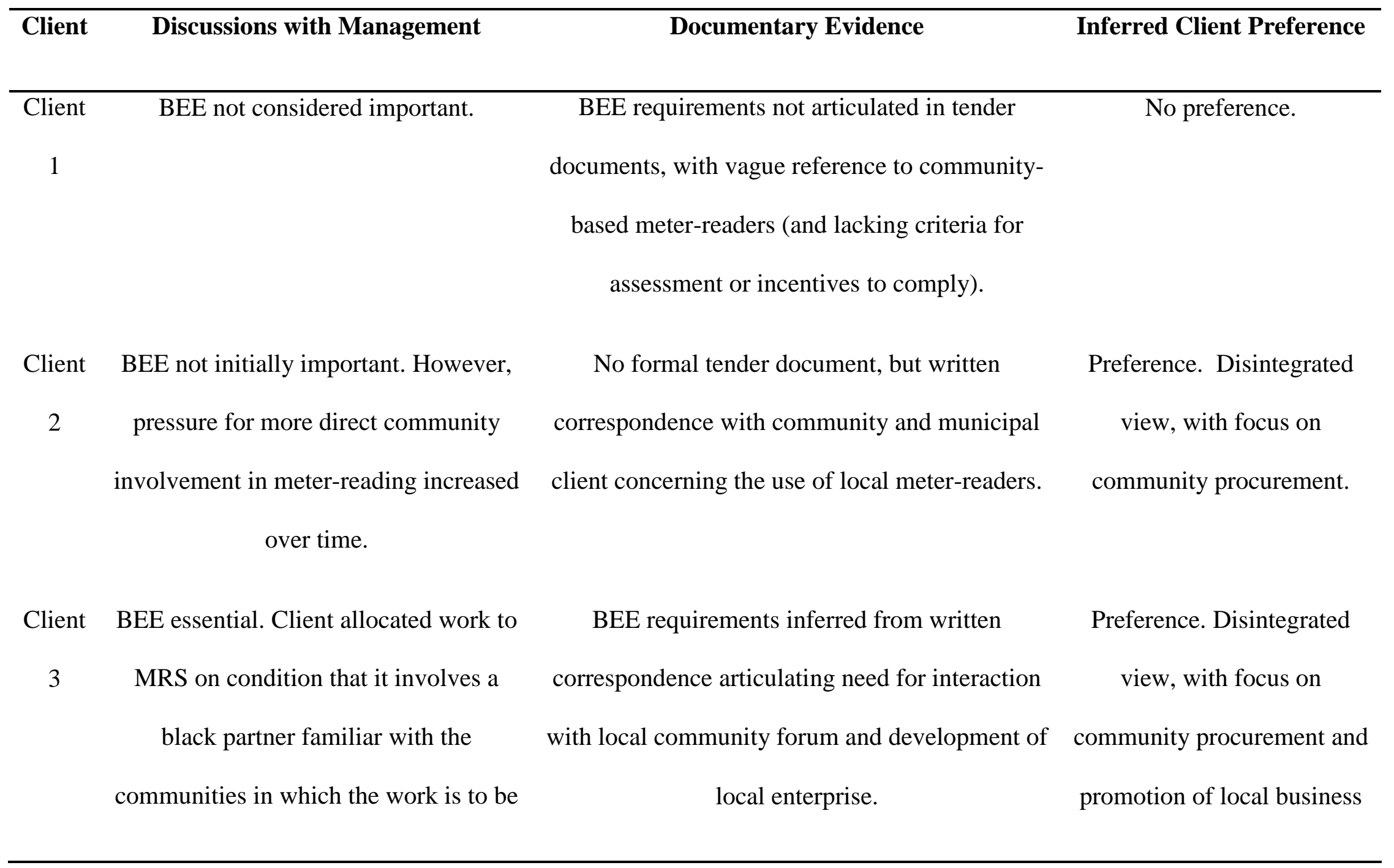


performed.

Client BEE essential. MRS contacted by black

4 partner to cooperate in a tender bid.

Client BEE not considered important.

5 Although information collected on this, no particular action required. specific procurement policy of local government, but emphasizing all of the factors mentioned in the national scorecard.

BEE requirements in tender documents based on

No formal tender document, but no reference to $\mathrm{BEE}$ requirements in written correspondence between MRS and client.
Preference. Disintegrated

view, with focus on

community procurement and promotion of local business

No preference. 
TABLE 5: MRS Response to Client Views of its Value Chain

\begin{tabular}{|c|c|c|c|}
\hline Client & Discussions with Management & Documentary Evidence & $\begin{array}{l}\text { Inferred } \\
\text { Boundary } \\
\text { Response }\end{array}$ \\
\hline $\begin{array}{c}\text { Client } \\
1\end{array}$ & $\begin{array}{l}\text { BEE not considered when bidding: "The proposal was } \\
\text { quite short, with just an outline of the service to be } \\
\text { rendered" }\end{array}$ & No reference to BEE in tender bid. & $\begin{array}{c}\text { None } \\
\text { (MRS delivers } \\
\text { integrated } \\
\text { service). }\end{array}$ \\
\hline $\begin{array}{c}\text { Client } \\
2\end{array}$ & $\begin{array}{l}\text { In response to community requests, MRS appointed } \\
\text { part-time meter-readers as well as a coordinator from } \\
\text { this area to collect meter readings. }\end{array}$ & $\begin{array}{l}\text { Written proposal to client and } \\
\text { correspondence with community coordinator } \\
\text { focus on training local meter-readers. }\end{array}$ & $\begin{array}{c}\text { Adjust } \\
\text { boundaries } \\
\text { (MRS focus on } \\
\text { planning and } \\
\text { processing) }\end{array}$ \\
\hline
\end{tabular}




\begin{tabular}{|c|c|c|c|}
\hline Client & MRS was contacted by a member of the communities & Written proposal to client emphasize role of & Adjust \\
\hline \multirow[t]{3}{*}{3} & within which meter-reading was to take place and & MRS in processing task and role of local & boundaries \\
\hline & agreed to form a joint venture, where the community & black partner in managing and executing & (MRS focus on \\
\hline & member would be responsible for planning and the & meter-reading (planning and collection). & processing) \\
\hline Client & Similar to Client 3 , MRS was contacted by a community & Tender bid details a joint venture with the & Adjust \\
\hline \multirow[t]{4}{*}{4} & member, who did not have the requisite experience. & community member, subdivision of tasks & boundaries \\
\hline & MRS decided to form a joint venture, where MRS is & show MRS involved in processing and & (MRS focus on \\
\hline & responsible for processing and the community member & community member in planning and & processing) \\
\hline & for planning and collection of readings. & collection. & \\
\hline Client & BEE not considered when bidding. & No reference to BEE in proposals to client. & None \\
\hline \multirow[t]{3}{*}{5} & & & (MRS delivers \\
\hline & & & integrated \\
\hline & & & service). \\
\hline
\end{tabular}


FIGURE 4

\section{Boundary Decisions of MRS by Client}

Client 1 and 5

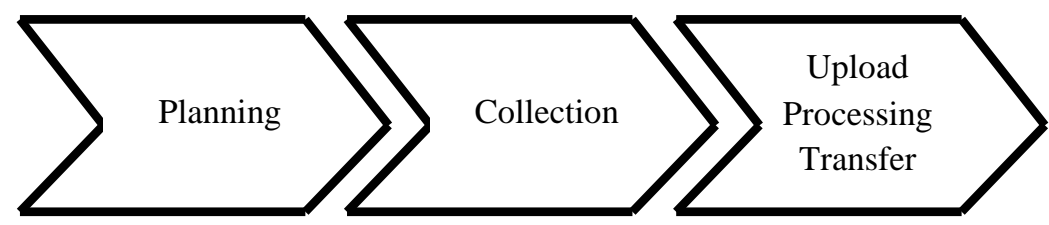

Client 2

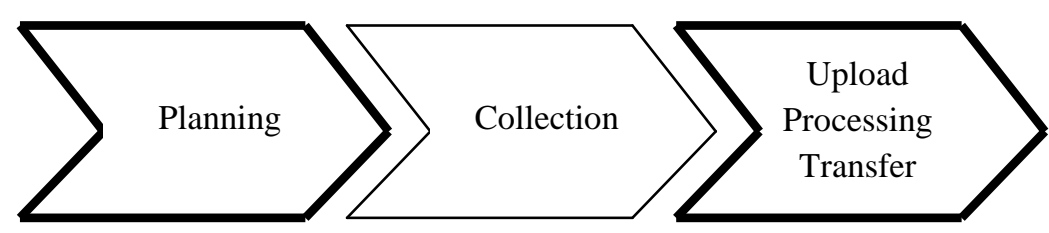

Client 3 and 4

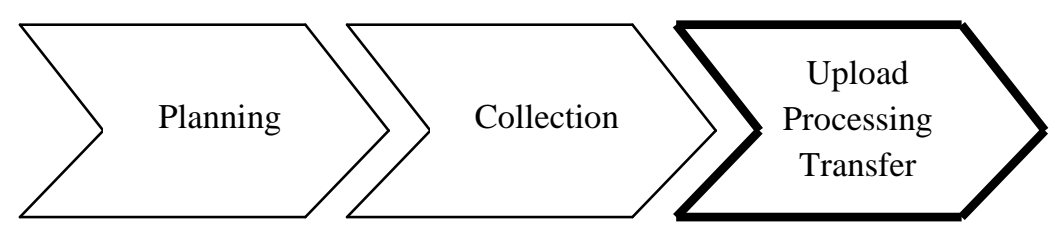


FIGURE 5

MRS Involvement across the Meter-reading Value Chain

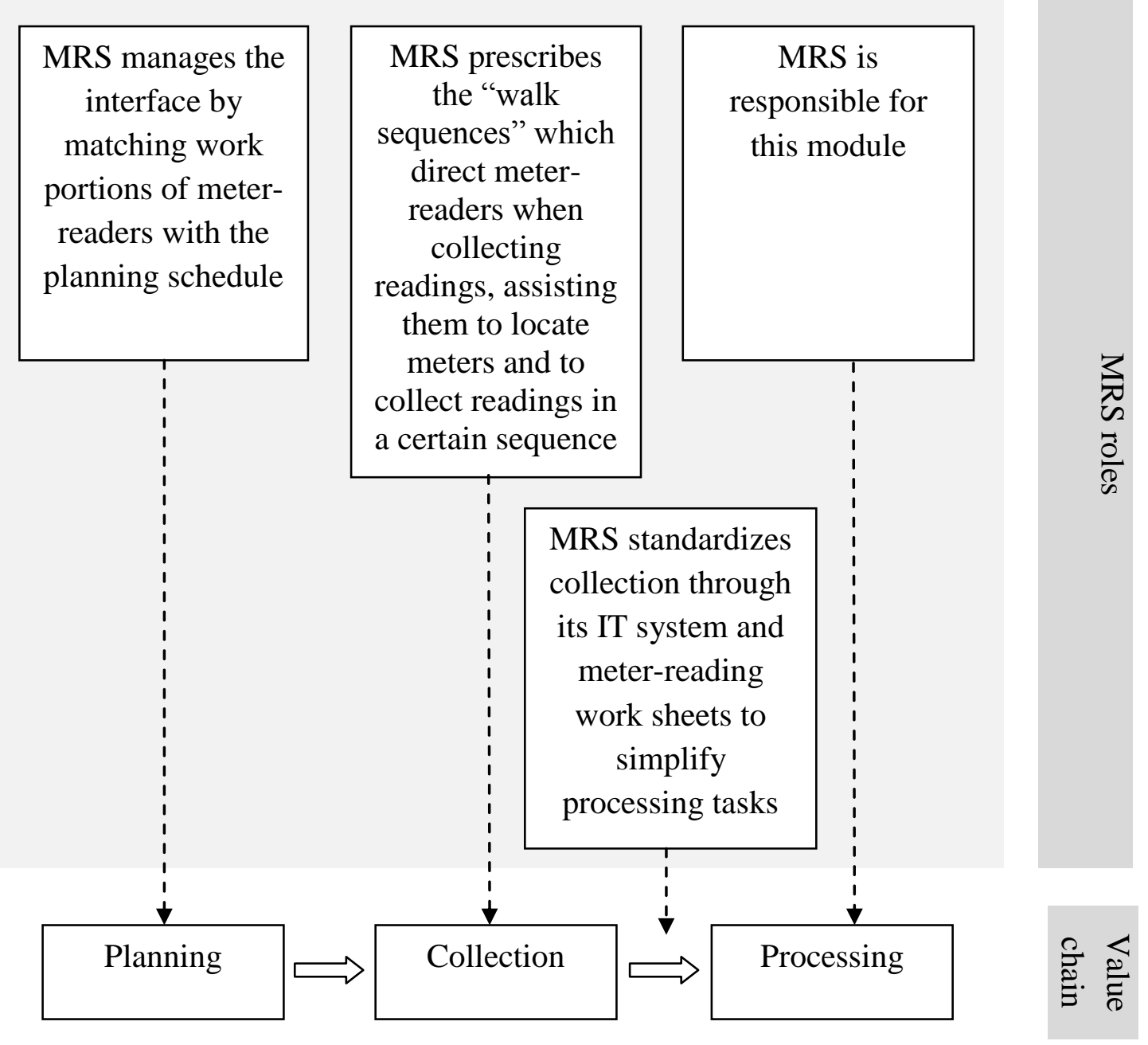

